\title{
Asian Drivers: Typologies and Questions
}

\section{Hubert Schmitz}

\section{Introduction}

There is agreement that first, the global economy is increasingly interconnected and second, economic power is shifting from the West to the East, in particular China. It follows that this shift in power will have ramifications for the rest of the world. The extent and form of these ramifications, however, are not clear. This article proposes some conceptual distinction and questions for organising future research on the implications for developing countries.

These implications are beginning to receive attention in the literature. Particularly useful are the studies of Lall and Albaladejo (2004), Mesquita Moreira (2004), Jenkins and Edwards (2004), Dussel Peters (2005 forthcoming) and Kaplinsky (2005b). Building on these works, a new research programme, initiated by the Institute of Development Studies and partner institutions, seeks to study the implications with greater depth and scope.

This programme is entitled 'The Impact of Asian Drivers on the Developing World' (IDS 2005). The notion of Asian Drivers is explained as follows: "From the late twentieth century, Asian economies, with more than half of the global population, began to play an increasingly important role as global producers. This revival began in Japan after the 1960s, and then spread to a limited number of small- and mediumsized East Asian economies during the last quarter of the century. At the dawn of the new millennium the momentum of Asia has been significantly strengthened by the very rapid growth of two very large economies - China and India, each with around 20 per cent of the global population, have seen sustained rates of economic growth exceeding 7 per cent annually. But it is not just these two economies which underlie Asias growing presence in the global economy. China in particular is integrated into a regional system of production involving a number of medium-sized economies such as Thailand and Vietnam, and India is actively beginning to pursue links with other South Asian regional economies. We refer to these newly dynamic and generally large Asian economies as the "Asian Drivers". These Asian Drivers are likely to have a significant impact on the global economy' (IDS 2005: 1, see also Kaplinsky's Introduction to this IDS Bulletin).

The programme then sets out an agenda for research on the effects of the Asian Drivers on the developing world, distinguishing between direct and indirect effects and between complementary and competitive impact. While the programme covers both changes in the sphere of trade and production and in the sphere of finance, this article is only concerned with the former, that is, changes in the "real economy". For an analysis of changing financial flows and their implications, see GriffithJones (2004) and Gottschalk (in this IDS Bulletin).

The main purpose of this article is to suggest a conceptual apparatus for future work and set out the key questions for researchers and policy-makers. Section 2 distinguishes between three types of Asian Drivers and indicates the analytical framework appropriate for examining these Drivers. Section 3 disaggregates the three types of Asian Drivers and sets out the new research questions that arise for each type. Section 4 connects the debate on Asian Drivers with the debate on regional integration, showing how the distinction between shallow and deep integration can help to bring together the best from new trade theory and value chain analysis. Section 5 introduces a matrix for organising the discussion of the effects of the Asian Drivers. The final Section 6 sets out some of the new questions to be confronted by policy-makers and practitioners.

\section{Types of Asian Drivers}

The central proposition of this article is that we distinguish between three types of Asian Drivers:

IDS Bulletin Vol 37 No 1 January 2006 ㄷ Institute of Development Studies 


\subsection{Asian Driver 1}

Asia (in particular China) is forcing other countries to react to its rapid growth and competitiveness. Due to its large size, China's rapid growth and competitiveness poses major challenges and provides new opportunities for others. This leads to a focus on changes in the quantity and direction of trade and has major implications for relative prices.

The tools for studying these changes come from standard trade theory and trade analysis. These tools have been employed in different ways by Jenkins and Edwards (2004), Lall and Albaladejo (2004), Dussel Peters (2005 forthcoming) and Kaplinsky (2005b). Their work advances, significantly, our understanding of the effect of this Asian Driver 1 on a range of developing countries in South and East Asia, and South and Central America. It considers not only the issues of trade creation and trade displacement, but how tradeinduced changes in relative prices affect incentives for producers and welfare of consumers. Stevens and Kennan take this work a significant step further: they suggest a methodology which makes it possible to include some of the indirect effects of the Asian Driver 1. They demonstrate the importance of including these indirect effects and show a practical way of assessing the overall impact of Asian Driver 1 on country X, Y or Z (for details, see Stevens and Kennan in this IDS Bulletin).

\subsection{Asian Driver 2}

Big changes in quantity and direction of trade driven by China are already manifest even though the full impacts remain to be examined. Simultaneously, other more subtle changes are on their way. Their significance is not yet clear but they deserve attention. Asia (in particular China) is actively setting the parameters for others, by coordinating global value chains and by influencing global standards. The former is carried out by new big buyers or investors. The latter takes the form of influencing the setting of standards (de jure) or making existing standards applicable or irrelevant (de facto). This leads to a focus on changes in the way production and trade are organised: (a) from within the chain, or (b) from outside the chain.

An example of parameters being set from within the chain is the Hong Kong-based company Li \& Fung which has become one of the world's leading supply chain coordinators, particularly in textiles and garments. The locus of such coordinating power has begun to move from the West to the East, but how far has it gone? Is the same trend observable in other sectors? Parameters can also be set from outside the chain, for example through the establishment of quality, labour or environmental standards by public or private institutions such as the International Standards Office (ISO), International Labour Office (ILO) or Forestry Stewardship Council (FSC). The question is how China and India's entry into the global economy will affect the relevance of such standards.

The global value chain (GVC) approach provides the analytical framework for studying these changes in the way production and trade is organised (www.globalvaluechains.org). The GVC approach is useful because it explicitly recognises that: first, the various activities are often carried out in different parts of the world, hence the term global value chain. Second, some activities add more value and are more lucrative than others. Third, some actors in the chain have power over the others. The powerful actors are often called the "lead firms" who seek to "govern" the chain. Chain governance means that lead firms set and/or enforce terms under which others in the chain operate. A central concern of value chain analysis is to understand the relationships between global lead firms and local producers, and the opportunities and constraints that result from entering such relationships. Recent research has shown that the organisation of the chain has a major impact on access to markets, acquisition of capabilities, the distribution of gains and the possibility of state intervention (Gereffi 1999; Humphrey 2005; Humphrey and Schmitz 2002; Kaplinsky 2005a; Morris et al. 2005 forthcoming; Nadvi and Thoburn 2004; Schmitz 2004).

The GVC approach certainly provides a firm analytical grip on the consequences of parameter setting and coordination from within the chain. However, there are also relationships with actors outside the chain and there are parameters set out from outside the chain which need to be considered. Take the case of standards: some are set and enforced from inside the chain, others from outside the chain. Various combinations are possible, as illustrated in Figure 1 (drawn from Humphrey and Schmitz 2001).

As will be explained later, the changes brought about by Asian Drivers 1 and 2, broadly approximate changes in "shallow integration" and "deep integration" respectively (Evans et al. 2004). There 
Figure 1: Parameter setting and enforcement from inside and outside the chain

\begin{tabular}{|c|c|c|c|}
\hline & \multicolumn{2}{|c|}{ Parameter monitoring and enforcement } \\
\hline & $\begin{array}{l}\text { Lead } \\
\text { firm }\end{array}$ & $\begin{array}{l}\text { 1. Specification of quality systems and } \\
\text { enforcement through audit, either directly by } \\
\text { the lead firm itself or through an agent acting } \\
\text { directly on its instructions. Requirement for } \\
\text { labour standards above the legally required } \\
\text { minimum, verified by the lead firm or its } \\
\text { agents. }\end{array}$ & $\begin{array}{l}\text { 2. Lead firm requires suppliers to conform to } \\
\text { a process standard or code of practice for } \\
\text { which an independent monitoring or } \\
\text { certification system exists. Examples would } \\
\text { include ISO 9000, ISO } 14000 \text { and SA } 8000 \\
\text { certification. }\end{array}$ \\
\hline 常 & $\begin{array}{l}\text { External } \\
\text { agents }\end{array}$ & $\begin{array}{l}\text { 3. Firms are expected not to use suppliers } \\
\text { that employ child labour, but this expectation } \\
\text { is not accompanied by any system for } \\
\text { enforcing the ban. The firms have to develop } \\
\text { their own enforcement systems. }\end{array}$ & $\begin{array}{l}\text { 4. The EU requires that surgical instrument } \\
\text { manufacturers exporting to the European } \\
\text { market must be ISO } 9000 \text { certified. The } \\
\text { certification is carried out by independent } \\
\text { certification agencies. }\end{array}$ \\
\hline
\end{tabular}

are, however, differences which will need to be clarified so that researchers from different traditions and with different vocabularies can communicate effectively in future work on Asian Drivers.

\subsection{Asian Driver 3}

In order to introduce Asian Driver 3, we need to step back and reflect further on Asian Drivers 1 and 2. The emergence of the latter reflects a major shift in production capability from the EU and US to East Asia. Europe and North America accepted the disappearance of huge parts of manufacturing industry, expecting that they would retain the innovation capabilities. In fact, one of the most striking facts about the global distribution of industrial activities is the massive dispersal of production capability away from the EU and US to the developing world, in particular to East Asia. It has occurred over the last 30 years but accelerated in recent years. The magnitude and speed of change in the global distribution of production capability is historically unprecedented. In contrast, innovation activities have remained remarkably concentrated in the EU and US (and Japan). This is beginning to change. We observe the build of innovation capabilities in China, India and other Asian countries, particularly in rapidly growing sectors such as electronics and software. The extent of this build-up of innovation capability is not yet clear (and contested in the literature) but it is clear that we are beginning to observe a qualitative transformation in the Asian Drivers, which is likely to have major implications for the rest of the world.

The notion of Asian Driver 3 tries to capture this. It suggests that the accumulation of innovation capability in China, India and other Asian countries has ramifications for the rest of the world. The hypotheses are first, the main losers are the developed countries. Second, the developing world will gain: new technology sourced from the East will be more accessible than technology from the West. Third, new production spaces will open up as the Asian Drivers are devoting more attention to innovation activities. These hypotheses might seem too future-oriented for an academic research programme, but business journals such as The Economist and Business Week are beginning to estimate job losses and gains due to the international relocation of innovation activities.

The analytical framework for analysing Asian Driver 3 comes from theories of innovation and of the knowledge economy. The central distinction in this body of literature is between knowledge-using and knowledge-creating activities (Bell and Albu 1999). The rapid build-up of production capability in Asian Drivers was due to very effective use of existing knowledge. However, the transition from knowledge using to knowledge creating does not automatically follow (Bell and Pavitt 1993). This is a key message of the innovation literature. So how did the Asian Drivers acquire the innovation capabilities? The innovation literature tells us that innovation requires (a) deliberate and substantial 
investment in equipment, people and organisation and (b) close interaction with others. Innovation as an interactive process has been the central concern in the burgeoning innovation systems literature (Lundvall 1992; Edquist 1997; Cassiolato et al. 2003). In itself, this innovation systems approach is not sufficient to analyse the changes in Asia but it provides important concepts and insights for analysing the acquisition of technological capabilities. It needs to be complemented with an understanding of how market opportunities and constraints influence the innovation process. This is exactly what Hobday (1995) provides in his analysis of latecomer firms in East Asia. Analysis of the Asian build-up of innovation capability and its implications for the rest of the world would further benefit from the global value chain approach because it helps to understand the influence of power of the lead firms and suggests a distinction between strategic and non-strategic innovation.

In conclusion, this section suggests that in order to understand the consequences of the Asian Drivers for changes in the real economy, it helps to distinguish between three types of Asian Drivers. Each type leads to a different focus:

- Changes in the quantity and direction of trade

- Changes in the way production and trade are organised

- Changes arising from the relocation of innovation activities.

These are not independent of each other. On the contrary, they are all interconnected and changes in the organisation of trade and location of innovation ultimately lead to changes in the quantity and direction of trade and in relative prices. Presumably future research will not just seek to record the final trade impact but understand the chain of causation. In order to understand the drivers of change one can draw on different conceptual and analytical frameworks. This section has tried to spell out briefly where the concepts and tools of analysis would come from.

\section{Disaggregating further and setting out the questions}

Future research on Asian Drivers programme requires conceptual innovation and modification but it requires above all new empirical research. For empirical purposes, each of three Asian Drivers can be unpackaged further.

\subsection{Asian Driver 1}

Here one can distinguish between Asian Drivers being a:

1. source of competition in domestic markets. For example, how has Pakistan's increase in imports from China affected the ability of local telephone manufacturers to compete in their domestic market? How has the availability of Chinese components impacted on Indonesia's motor cycle industry?

2. source of competition in third markets. For example, how has the increase in China's shoe exports to the EU affected the Brazilian shoe industry? How does India's premier position in the global software industry affect the ability of newcomers from the Middle East or North Africa to enter the market?

3. source of demand. For example, how has the Chinese demand for Indonesian wood affected the Indonesian furniture industry? How has the Chinese demand for leather affected the East African economies? Will China's growth in garment exports provide a new market for the cotton-spinning and weaving industry of Pakistan or Egypt?

Each of these competitive and complementary effects has an impact on relative prices. Two price impacts can be distinguished: first, changes in relative prices and hence incentives for producers. For example, as a result of China's expansion, many producers of raw or semi-processed commodities in Latin America have benefited from rapid price increases and many producers of manufactured products have suffered from declining prices. Second, there can be an impact on welfare of consumers. Both falling and rising prices can be observed: contrast, for example, the declining prices in home electronics with the recently rising prices in energy for consumers in most parts of the world. China's growth and transformation seems to have played a major role in both.

\subsection{Asian Driver 2}

1. source of coordination. For example, how has the increasing prominence of Li \& Fung (biggest Asian supply chain coordinator) affected the growth and upgrading prospects of Thailand's or Egypt's textile industry? Hong Kong and Shanghai have emerged as hubs for producer services in design, procurement, logistics, and 
marketing; how does this affect the growth and upgrading prospects in sectors $\mathrm{X}, \mathrm{Y}, \mathrm{Z}$ of the Philippines and Indonesia?

2. source of foreign direct investment. For example, how has Chinese foreign direct investment affected the Vietnamese motorcycle industry? How has it affected the Nigerian furniture industry? How does East Asian foreign direct investment in the garment industry of Southern Africa influence the growth and upgrading prospects of this industry?

3. source of rule changes. For example, how does India's position on Intellectual Property Rights (IPR) affect the growth and upgrading prospects of its own pharmaceutical industry or that of neighbouring countries? How has the increase of Chinese garment exports affected the strategies of exporters in Bangladesh or other countries, in particular with regard to compliance with labour standards. Does China's massive increase of exports, in spite of poor compliance with labour standards, undermine efforts to improve compliance with labour standards in competing countries?

\subsection{Asian Driver 3}

1. source of new technology. How has the emergence of China as innovator in household goods affected the terms of access to new technology for other developing countries? Does it matter whether the innovators are foreign or domestic firms? Does the fact that Taiwan has become an innovator in some parts of the electronics industry make it more or less difficult for other latecomer countries to make the transition from production to innovation capability?

2. source of new market niches. Does the emergence of India as software innovator open up new opportunities for Egyptian software producers? Does Taiwan's emergence as innovator in lap top computers open up new spaces for component producers or assemblers in other parts of East Asia? Does it make a difference for these producers whether the innovation emanates from the US or Taiwan?

\section{Shallow and deep integration}

In order to be relevant, future research on Asian Drivers needs to integrate competences from different fields: trade theory, value chain analysis, innovation theory. Bringing together the first two is particularly important with respect to Asian Drivers 1 and 2 .

In order to bring together groups with different competences, it is essential to learn each others' language. This section takes such a first step with regard to two groups: trade economists and value chain analysts. The former have recently introduced the distinction between shallow and deep integration. It is a distinction which is intuitively easy to grasp and helps to build a bridge.

Shallow and deep integration are not analytical categories in standard trade theory. They are however part of a new theory of trade and regionalism which pays attention to the links between deep integration, productivity and trade (Evans et al. 2004, 2005). In a nutshell, shallow integration refers to a situation in which trading links become closer (e.g. due to a regional trade agreement) and where only the volume, prices and direction change. In contrast, deep integration occurs when trading partners develop common regulatory frameworks which facilitate the regional division of labour and influence the way goods are produced and traded. The new trade theorists are particularly interested in the effect of regional trade agreements on the depth of integration because of its potential impact on productivity.

Value chain analysts are also interested in deep integration even though they do not use this term. For Gereffi (1999: 41), the key feature of the current phase of globalisation is the "functional integration and coordination of internationally dispersed activities'. Central to this integration is that 'some firms in the chain set and/or enforce parameters under which others in the chain operate' (Humphrey and Schmitz 2001: 20). In other words, value chain analysis focuses primarily on the parameters that are set by enterprises from within the chain and it shows how the chains' lead firms influence the where, who, what, how, and when of production. In contrast, the new trade theorists focus on parameters set from outside the chain, in particular through the introduction of regional trade agreements (Evans et al. 2004, 2005).

Asian Driver research requires both perspectives: deep integration from within and deep integration from outside the chain. Figure 1 (see Section 2) can be seen as a first step in bringing together parameter setting and enforcement from inside and outside the chain.

While research on Asian Driver 1 is essentially concerned with changes in shallow integration, research on Asian Driver 2 concerns deep 
Figure 2: Matrix of the effects of Asian Drivers

\begin{tabular}{lcccccc}
\hline & \multicolumn{2}{c}{ Asian Driver 1 } & \multicolumn{2}{c}{ Asian Driver 2 } & \multicolumn{2}{c}{ Asian Driver 3 } \\
\hline & Direct & Indirect & Direct & Indirect & Direct & Indirect \\
\hline $\begin{array}{l}\text { Compete } \\
\text { Complement }\end{array}$ & & & & & & \\
\hline
\end{tabular}

integration. Is this deep integration driven by new Asian lead firms? How have regional trade agreements affected this integration? Why has deep integration occurred in East Asia without formal regional trade agreements? How has a natural trading bloc emerged in this region? What are the implications for other developing countries?

\section{Categorising the implications of Asian Drivers}

In working out the effects of Asian Drivers 1,2 and 3 , an agreed vocabulary will help. Here we can draw on the distinctions used in IDS (2005), especially the distinctions between (a) direct and indirect and (b) competing and complementary effects. All these distinctions can be brought together in a matrix (Figure 2) which should help organise the discussion of research strategy and findings.

The matrix looks neat but tracing the effects is inevitably messy. The question is whether there are methods for cutting through the complexity in costeffective ways. Stevens and Kennan (in this IDS Bulletin) suggest an effective way for tracing the impact of Asian Driver 1 on say Ghana or Pakistan. Their method will also help to identify which sectors would be useful candidates for studying in detail the effects of Asian Driver 1 on the countries in question. In order to study the impact of Asian Drivers 2 and 3, it is probably best to opt straight away for a sectoral approach. The Annex (Section 7) suggests a way for selecting the sectors.

\section{New questions for policy and practice}

This article has suggested distinctions for decomposing the Asian Driver and its effects. And it has given examples of the kind of questions that need to be addressed in future research. The research agenda is huge but does it sufficiently reflect the concerns of those involved in policy making? The fundamental question is whether the shift in power from the West to the East matters for global governance and national governance. The global governance issues are addressed by Humphrey and Messner in this IDS Bulletin. The question addressed in this article is whether and how the emergence of the Asian Drivers matters for strategising and policy making at the national level, for example Ghana, Pakistan or Mexico? Does the answer differ according to whether the country is in Eastern Asia (participating in the regional division of labour) or outside it?

Take for example the case of Indonesia. It is a particularly interesting country because it has a substantial industrial sector, is located near the rapidly growing East Asian region but deep integration remains limited. Where and how does Indonesia's industrial strategy need to change? Does the sectoral targeting need to change? Is it necessary to change from supporting firms that produce and market their own complete products to supporting firms that occupy niches in global chains coordinated by others? Does it matter whether these chains are coordinated by European or Chinese firms? Is there a need to apply different policy instruments in view of the lessons learnt from China?

Such questions need to be asked also by donor agencies seeking to support Indonesia's industrial development. Numerous agencies have set up projects concerned with strengthening small and medium enterprises, the competitiveness of particular regions, technological capabilities in particular sectors and so on. The effectiveness of their contributions varies and remains controversial. The rise of the Asian Drivers raises new questions. Are these donor agencies equipped to provide constructive assistance which takes into account the rapid changes in China and India? Or do they trap the recipient in the past, due to consultants whose thinking is overly influenced by experiences or myths from the old powers in the EU, US or Japan?

If these are good questions, policy-makers will want to know how they can quickly find the answers 
Table 1: Criteria for selecting sectors: expected relevance with regard to different drivers of change

\begin{tabular}{|c|c|c|c|c|c|c|}
\hline Source of change & Garments & $\begin{array}{l}\text { Mobile } \\
\text { phones }\end{array}$ & $\begin{array}{l}\text { Motor- } \\
\text { cycles }\end{array}$ & Software & Horticulture & $\begin{array}{l}\text { Pharma- } \\
\text { ceutical }\end{array}$ \\
\hline \multicolumn{7}{|l|}{ Asian Driver 1} \\
\hline $\begin{array}{l}\text { 1. Competition in domestic } \\
\text { market }\end{array}$ & $x$ & & $x$ & & $x$ & \\
\hline 2. Comp. in third markets & $x$ & $x$ & $x$ & & & $x$ \\
\hline 3. Source of demand & $x$ & & & & $x$ & \\
\hline \multicolumn{7}{|l|}{ Asian Driver 2} \\
\hline 4. Coordination & $x$ & $x$ & $x$ & $x$ & & \\
\hline 5. FDI & $x$ & & $x$ & & & \\
\hline 6. Changing rules & $x$ & & & & & $x$ \\
\hline \multicolumn{7}{|l|}{ Asian Driver 3} \\
\hline 7. New technology & & $x$ & & $x$ & & \\
\hline 8. New market niche & & $x$ & & $x$ & & \\
\hline
\end{tabular}

and use the insights to bring about quick change in strategy and policy. They will need the researchers' contribution but is it enough? Do they need a task force that works on a new industrial strategy, is composed of national and foreign experts, and involves the key stakeholders in this work? The answer is almost certainly 'yes'.

\section{Annex: sectoral approach}

Research on the Asian Drivers will require both sector and macro-level research. The matrix in Section 5 would help to structure such research on changes in the real economy. The problem is that the effects of the Asian Drivers, drawn together in that matrix (see Figure 2), vary enormously by country and sector. This has implications for research design. The suggestion made here is to proceed by concentrating on selected sectors.

This in turn throws up the question of how to select these sectors. To this end, one could draw on wellknown classifications of industrial sectors (labour intensive, capital intensive, knowledge intensive; or low tech/hi tech; or mature/immature, etc.) But this would probably be a waste of time. It seems more sensible to ask which sectors would best illuminate the changes brought about by Asian Drivers 1, 2 and 3 and then select sectors accordingly. Or one can go further and use the disaggregation of the three Drivers suggested in Section 3. This disaggregation, by source of change, is reproduced in the left column of Table 1. Using the example of sectors, Table 1 suggests which sector is likely to illuminate changes in which respect. For example, the pharmaceutical industry is a clear favourite for 6 and software a clear favourite for 7 and 8 . Some sectors will help illuminate changes in several fields simultaneously, thus providing economies of scope. The motorcycle industry has the potential of revealing changes in 1,2,4 and 5. The garment industry might be relevant with regard to 1-6.

This type of matrix helps to structure discussion on which sectors to study. The listed sectors represent strong candidates but are only indicative examples. The ' $x$ ' indicates which aspect of Asian Drivers they might illuminate. The key point is procedural, namely to discuss the merits of preferred sectors by asking which aspect of Asian Drivers they would illuminate. Given scarce resources for research, it seems best to concentrate on sectors which are most likely to show the changes that are under way. Such decisions would be taken with very imperfect knowledge but it would help to keep the discussion focused on the changes emanating from the Asian Drivers. In other words, it will help researchers to be question-driven and saves them from being driven by concepts or classifications designed by others for different purposes. 


\section{References}

Bell, M. and Albu, M., 1999, 'Knowledge systems and technological dynamism in industrial clusters in developing countries', World Development, Vol 27 No 9: 1715-34

Bell, M. and Pavitt, K., 1993, 'Technological accumulation and industrial growth: Contrasts between developed and developing countries', Industrial and Corporate Change, Vol 2 No 2: 157-209

Cassiolato, J.E., Lastres, H.M.M. and Maciel, M.L. (eds), 2003, Systems of Innovation and Development: Evidence from Brazil, Cheltenham: Edward Elgar

Dussel Peters, E., 2005 forthcoming, Opportunities and Economic Challenges Posed by China for Mexico and Central America, Bonn: German Development Institute

Edquist, C. (ed.), 1997, Systems of Innovation: Technologies, Institutions and Organizations, London: Pinter

Evans, D., Holmes, P., Iacovone, L. and Robinson, S., 2004, 'A framework for evaluating regional trade agreements: deep integration and new regionalism', report to DFID, mimeo, University of Sussex, December

Evans, D., Gasiorek, M., Holmes, P., Iacovone, L., Jackson, K., Robinson, S. and Rollo, J., 2005, 'A framework for evaluating regional trade agreements involving developing countries', report to DFID, mimeo, University of Sussex, March

Gereffi, G., 1999, 'International trade and industrial upgrading in the apparel commodity chain', Journal of International Economics, Vol 48: 37-70

Griffith-Jones, S., 2004, 'Asian Drivers: international financial and macro-economic implications globally and for developing countries', mimeo, Brighton: Institute of Development Studies, University of Sussex, November

Hobday, M., 1995, Innovation in East Asia, Aldershot: Edward Elgar

Humphrey, J., 2005, 'Shaping value chains for development: global value chains in agribusiness', report prepared for GTZ, Brighton: Institute of Development Studies

Humphrey, J. and Schmitz, H., 2002, 'How does insertion in global value chains affect upgrading in industrial clusters?', Regional Studies, Vol 36 No 9: 1017-1027
Humphrey, J. and Schmitz, H., 2001, 'Governance in global value chains', IDS Bulletin, Vol 32 No 3: 19-29

IDS, 2005, 'The impact of Asian Drivers on the developing world', mimeo, Brighton: Institute of Development Studies, University of Sussex, February

Jenkins, R. and Edwards, C., 2004, 'How does China's growth affect poverty reduction in Asia and Latin America?', report to DFID, mimeo, Norwich: Overseas Development Group, University of East Anglia

Kaplinsky, R., 2005a, Globalization, Poverty and Inequality, Cambridge: Polity Press

Kaplinsky, R., 2005b, 'Revisiting the terms of trade revisited: will China make a difference?', mimeo, Brighton: Institute of Development Studies, University of Sussex

Lall, S. and Albaladejo, M., 2004, 'China's competitive performance: a threat to East Asian manufactured exports?', World Development, Vol 32 No 9: 1441-6

Lundvall, B.A., 1992, National Systems of Innovation: Towards a Theory of Innovation and Interactive Learning, London: Pinter

Mesquita Moreira, M., 2004, 'Fear of China: is there a future for manufacturing in Latin America?', mimeo, Washington, D.C.: Integration Department, Inter-American Development Bank

Morris, M., Barnes, J. and Esselaar, J., 2005 forthcoming, 'Globalisation, the Changed Dynamics of the Clothing and Textile Value Chains and the Impact on Sub-Saharan Africa', in O. Memodovic (ed.), Global Value Chains and Production Networks: Prospects for Upgrading by Developing Countries, Vienna: UNIDO

Nadvi, K. and Thoburn, J., 2004, 'Vietnam in the global garment and textile value chain: impacts on firms and workers', Journal of International Development, Vol 16 No 1: 111-23

Schmitz, H. (ed.), 2004, Local Enterprises in the Global Economy: Issues of Governance and Upgrading, Cheltenham: Edward Elgar

Stevens, C. and Kennan, J., 2005, 'Opening the package: the Asian Drivers and poor-country trade', mimeo, Brighton: Institute of Development Studies, University of Sussex, April 